\title{
The trust Fund of Phaenia Aromation (IG V.1 1208) AND IMPERIAL GYTHEION
}

\author{
Kaja Harter-Uibopuu
}

\begin{abstract}
In the small town of Gytheion in southern Laconia two marble blocks were found, containing the regulations for a trust fund from the year 42 AD (IG V.1 1208; SEG 13.258). The text will be presented with new emendations and an English translation. In my commentary I present the general background of the donor, Phaenia Aromation, and concentrate on a discussion of juridical problems that the text poses. A detailed analysis of the procedural prescriptions forms the centre of this paper.
\end{abstract}

The inscription that I would like to discuss in the following article had been found in a vinery in Gytheion in southern Laconia consisting of two marble blocks. The stones had been copied by P. LeBas and were then edited by P. Foucart. ${ }^{1}$ A new edition was provided by W. Kolbe, enriched with comments by U. von Wilamowitz-Moellendorff and presented in IG V.1. The latest emendations of the Greek text were made by A. Wilhelm (SEG 13.258). Unfortunately his article does not state clearly, whether he was able to read the squeezes or to see the stones in original, or whether they had already been lost at his time. ${ }^{2}$ The inscription provides interesting information on the administration of imperial Gytheion, especially when you combine the information taken from this stone with SEG 11.923, the famous hieros nomos on the imperial cult in Gytheion, stemming from the year 15 AD. Since the text can be taken as a good example of a description of daily life of Romans in a Greek town, I would like to illustrate the general background before concentrating on legal aspects of the text and presenting some new readings.

The inscription clearly stems from imperial times. P. Foucart dated it to the second century AD because of the mentioning of the Sebastoi in 1.37, whom he believed to be Marcus Aurelius and Lucius Verus ${ }^{3}$. A. Wilhelm solved the problem differently. The two letters in 1. 64, OB, had up to his time been read as the abbreviation of a name Ophellius Bomation, who was a member of the family of the donor Phaenia. Still the identity would not have been clear: the name of the phrontistēs is Ophellius Crispus, the name of the freedman Phaenius Primus. The combination of the two letters did not make much sense. A. Wilhelm found out that the name of the donor should be read Aromation instead of Bomation (1.61). He took the two letters in the last line to be a date, which brought him to the 72nd year to be counted from the battle of Actium as it is commonly done on the Peloponnesos in imperial times - resolving in the year $41 / 2 \mathrm{AD}$ as the date of the inscription. ${ }^{4}$ Since in 1.36 Livia is called $\Sigma \varepsilon \beta \alpha \sigma \tau \eta \dot{~} \Theta \varepsilon \dot{\alpha}$, we can restrict the possible date to the year $42 \mathrm{AD}$, the time after her consecration. ${ }^{5}$

\footnotetext{
${ }^{1}$ LeBas - Waddington 1837: 124 (243a); this text was presented with slight alterations by B. Laum (1914: 11-14, Nr. 9).

${ }^{2}$ Wilhelm 1951: 90-100. I was not able to locate neither the stone nor the squeezes myself.

${ }^{3}$ LeBas - Waddington 1837: 125.

${ }^{4}$ Wilhelm 1951: 92. Cf. IG V.1 1529 (Alagonia).

${ }^{5}$ Cf. Grether 1946: 222-252.
} 


\section{Phaenia Aromation and her family}

The small town Gytheion in southern Laconia had not been independent for the greatest part of her history. It was only after Flamininus' attack in $197 \mathrm{BC}$ that she was freed from Spartan dominance like all the other coastal towns in Laconia and put under the protectorate of the Achaean Koinon. After a short period of being Spartan again under Nabis, the perioecic towns were connected in the Kotvòv $\tau \tilde{\omega} v$ $\Lambda \alpha \kappa \varepsilon \delta \alpha$ uoví $\omega v$, which was transformed into the Koเvòv $\tau \tilde{\omega} \nu$ 'E $\lambda \varepsilon v \theta \varepsilon \varrho 0 \lambda \alpha \kappa \omega \nu \omega \nu$ by Augustus. He loosened the ties between Sparta and Gytheion even more by giving Kardamyle to Sparta, in order to grant the old city a new access to the sea, and thus leaving Gytheion free. ${ }^{6}$ Still the close connections between the two cities did not end, as the inscriptions show. SEG 11.923 demonstrates that - next to the emperors - C. Iulius Eurycles and his son C. Iulius Laco, two famous Spartans, were honoured as euergetès and kédemōn of the Koinon and the Polis. Two days of the week-long festival were celebrated in their memory. ${ }^{7}$ Later on the great-grandson of Laco was honoured in an inscription (IG V.1 1172), and we might well conclude that in the meantime there must have been similar decisions. Nevertheless we have to state that the close connections between Gytheion and Sparta were on an economic and personal basis, whereas politically the two towns were independent from each other.

Of great importance for the wealth of the Gytheates - and the foreigners living in their region - were the harbour as well as the marble and the purple. These three attracted strangers like Herodes Atticus who had an estate in this region and who was honoured by the polis (IG V.1 1171). Funerary epigraphs tell of even more foreigners who brought the money to the city. ${ }^{8}$ U. Kahrstedt shows that there had been no "old" citizen-families taking care of the necessary expenses of the city. This responsibility was taken on by the foreigners living in Gytheion. An inscription from the 1st cent. $\mathrm{BC}$ shows that in times of great financial troubles the two Roman negotiatores Marcus and Nemerius Cloatius lent the city money — on an enormous interest. ${ }^{9}$ Maybe the families of Phaenia Aromation, the donor of our trust fund, will have belonged to this group of wealthy Romans too.

As mentioned above, the reading of the cognomen of the donor Phaenia was corrected by A. Wilhelm as being Aromation instead of Bomation. ${ }^{10}$ From the typical ending on -ion we may well conclude that she had been a slave and was freed by a member of the gens of the Phaenii. This gens is well known in Italy as ointment and incense traders, the inscriptions show them to be thurarii. ${ }^{11}$ Most of the family members found in the inscriptions were freedmen themselves, the Greek cognomina show close contact to that part of the Mediterranean, although the Phaenii in Gytheion are the

\footnotetext{
${ }^{6}$ Chrimes 1952: 435-441; Bowersock 1965: 91-95; Harter-Uibopuu 2003: 217-221.

${ }^{7}$ SEG 11.923, 11. 19-22; Cf. Wenger 1929: 322-324.

${ }^{8}$ Paus. 3.21.6-3.22.2; Kahrstedt 1954: 203-207, cf. Bursian 1872: 144-146.

${ }^{9}$ IG V.1 1146; Le Roy 1978: 260-266.

${ }^{10}$ This name is attested in two other inscriptions, one from Italy (IG XIV 2475) and the other from Mylasa (IK Mylasa 22).

11 CIL VI 5680; 0032; X 1962; 6802; AE 1979, 124 (Via Appia, Rome): L(ucio) Faenio Polybio thurar(io) / L(ucio) Faenio Gelado thurar(io) / L(ucio) Faenio Iucundo / Faeniae Moschidi / Faenia L(ucii) f(ilia) Procula fecit et / M(arco) Livio Maximo parentibus et / fratri et filio et sibi et / libertis libertabusque suis / posterisque eorum omnium. Cf. d'Arms 1981: 167-168.
} 
only ones attested in mainland Greece. The Ophellii, on the other hand, were a gens well represented throughout Greece, and it is quite probable that Phaenia Aromation married a member of this family. Her phrontistess and kyrios is P. Ophellius Crispus who might have been her son. We find the Ophellii attested in Athens, Olympia, Kos, Melos and Paros, but their first basis in the eastern Mediterranean seems to have been Delos, where they lived as traders from the 2 nd cent. BC on. ${ }^{12}$ They prospered as negotiarii and had a leading role in the life of the Italic community. Maybe it was trading business that brought them to Laconia - as we have seen, Gytheion was a famous port.

As for Phaenia's personal status, the end of the inscription shows some more details. She was Roman like her kyrios P. Ophellius Crispus. She does dispose of her wealth herself, but it is her phrontistēs and kyrios who gives his auctoritas to her deed. He might either have been her husband or more probably her son. One of these two should have taken over the tutela as being her agnate kin. Still we cannot be sure beyond doubt on the question of her familiar relation to her kyrios, since there was the possibility for women to choose these tutores themselves. In an article on women and trust funds, $\mathrm{H}$. Taeuber points out that one of the main differences between Greek and Roman law in this aspect was that the Greek women did not need a kyrios to donate a large sum of money, whereas the Roman women did need their tutor mulierum. ${ }^{13}$ Still we do know from the Egyptian papyri that women of Greek origin did need a kyrios as well, usually this task was taken on by their husbands or - if they were already widows - by their grandfathers, brothers or sons of age. This kyrios was needed for legal transactions of a larger economic significance like divorce, contract of marriage, loans, testating, changing of a last will or sales of land. ${ }^{14}$ Striking in this inscription is that P. Ophellius Crispus is not only kyrios (tutor) but also phrontistēs, which could be translated as curator. A curator could have been appointed by any person for any legal transaction, but usually this was only done for special acts. Phaenia would not have needed a curator since she already had her tutor, but of course this was not impossible by Roman law. L. Mitteis is quite strict in his verdict on this procedure: he calls it bad provincial style. ${ }^{15}$ We do find this "pleonasm" again in a manumission decree from Delphi of the 1st cent. AD. ${ }^{16}$ I would rather suggest that the aim of Phaenia as well as Donata in Delphi was more to have everything done "overcorrectly" and it had less to do with their not understanding the subtleties of Roman law. They will have wanted to ensure their legal transactions against any challenge maybe they had already had bad experiences, we will not know. The last lines of the inscription are quite interesting in their form: the text is concluded with a hypographe, a signature. This form - which is quite regular in the papyri - is not found in any other inscription from mainland Greece or Asia Minor apart, of course, from letters. ${ }^{17}$

\footnotetext{
${ }^{12}$ IG II $^{2}$ 2026; 2471; 7131; 10161; IG IV 145; IvO 443; ICos 228.32; IG XII.3 1234; IG XII.5 377; IDélos 3-5 1681; 1766; 2616.

${ }^{13}$ Taeuber 1994: 199-219.

${ }^{14}$ Kaser 1955: 311-315, Rupprecht 1986: 95-102.

${ }^{15}$ Mitteis 1891: 155-156.

${ }^{16}$ FD 3.6 126, 1. 7.

${ }^{17}$ Cf. PGrenf II 71rp, 2, 1. 20; PKoeln II 85, r, 1. 10; PLond III 1168, r,2, 1. 15; PLond III 1164, F, 1. 31 et al. For the epigraphic evidence of the formula in correspondence: Syll. ${ }^{3} 821$ C, 1. 4; D, 1. 2; IG XII.2 35, b, 1. 27; IvEphes. 218, 1. 2.
} 


\section{The trust fund and its regulations}

A trust fund in Greek and Roman antiquity was — quite similar as today — a certain amount of capital either donated to the city or a sanctuary or alternatively designated for setting up and running a private association. The purposes for which the beneficiary had to use the donation might vary from public business (like e.g. the running of a state educational system as in Teos) to private concerns (as the annual commemoration of the benefactor in the form of a tomb cult). The terms under which the capital was to be administered were usually very well specified. The city or sanctuary would not be allowed to spend the capital itself but would be obliged to put the capital to work by farming it out, and defray the costs associated with the purposes of the trust fund from the interest accumulated. In our case the donor is a woman, which is quite common in the Greek world. B. Laum supposes that roughly $15 \%$ of all trust funds had been donated by women. ${ }^{18}$ Especially under the influence of Roman law in imperial times the rights of women to have their own property and dispose of it on their own increased. Next to the private benefit, the aim of these trust funds was usually to ensure that a certain aspect of public life was taken care of. We find women establishing a new agōn in Phaselis or giving money for the hiring of actors in Korkyra. ${ }^{19}$ Here in Gytheion, Phaenia Aromation financed the supply of oil for the gymnasion.

1

$-----------------------------v i ́$ ov

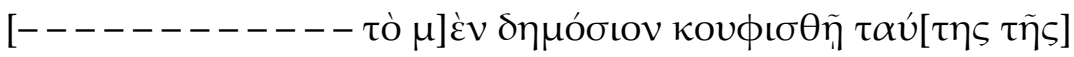

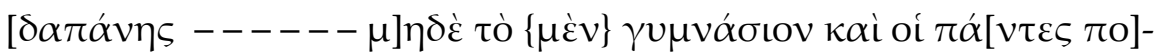

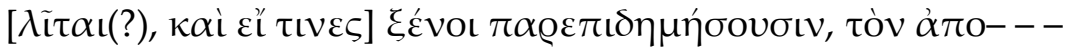

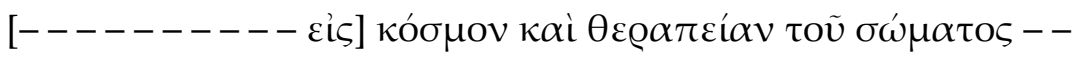

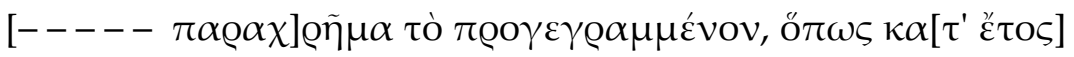

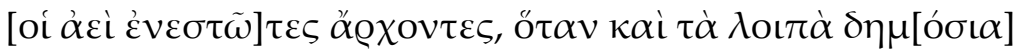

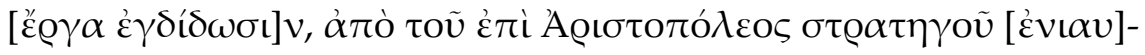

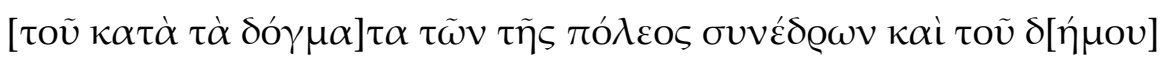

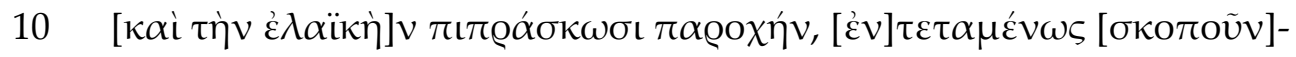

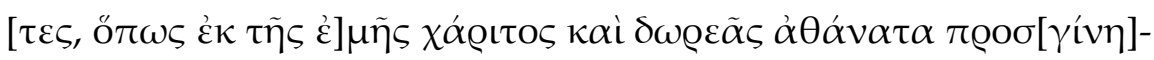

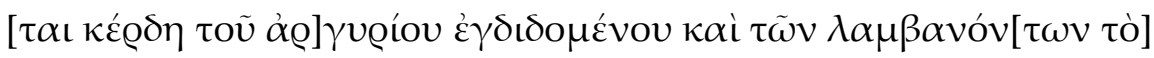

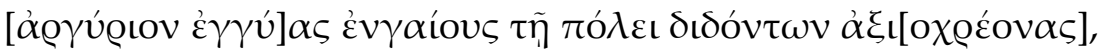

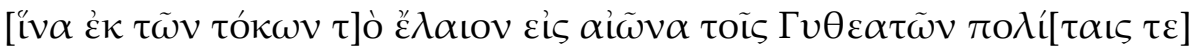

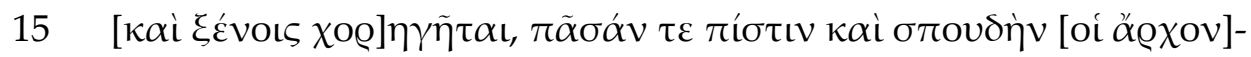

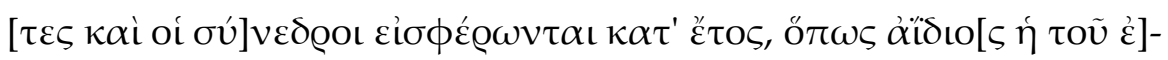

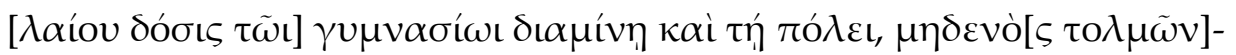

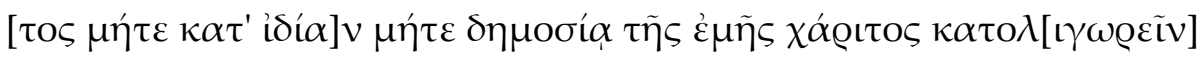

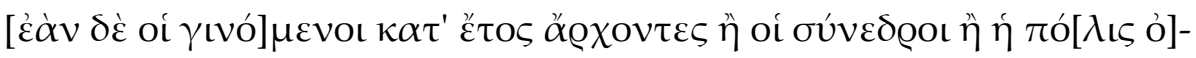

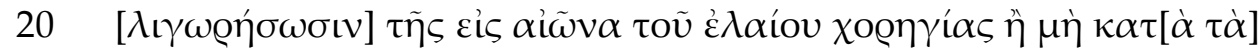

\footnotetext{
${ }^{18}$ Cf. Laum 1914: 1-2, 23-26.

${ }^{19}$ Taeuber 1994: 208-214.
} 


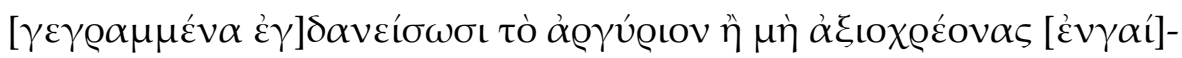

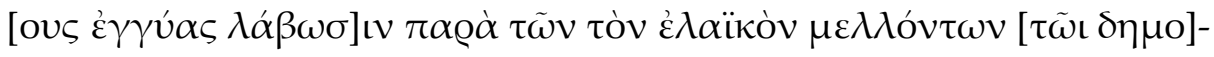

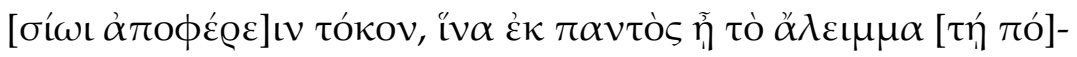

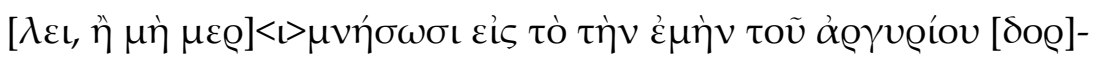

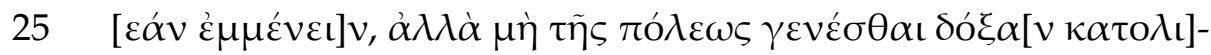

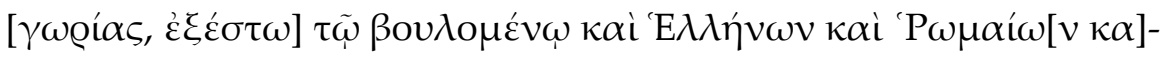

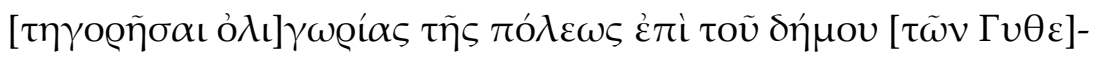

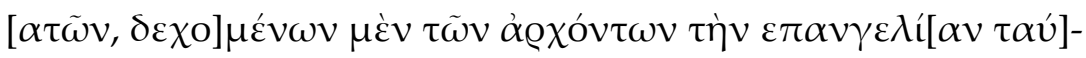

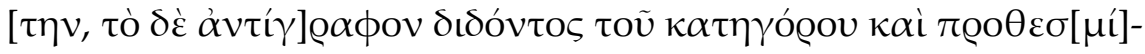

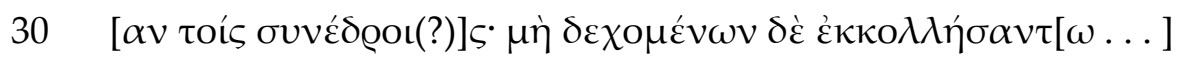

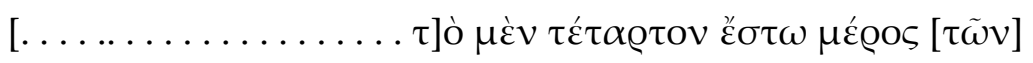

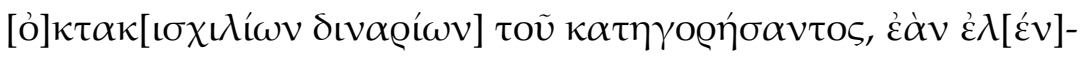

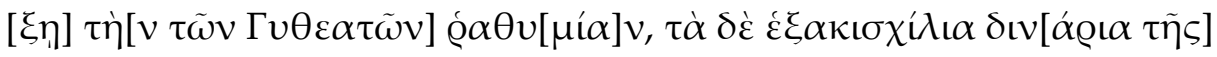

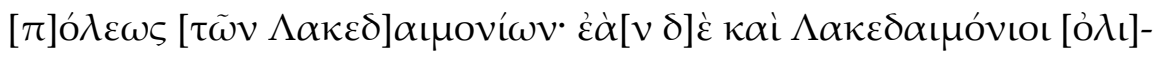

$35[\gamma \omega]$ ]

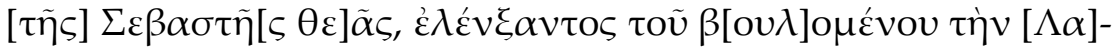

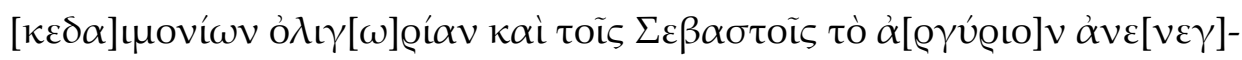

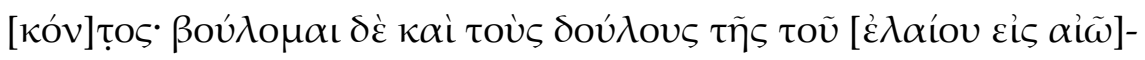

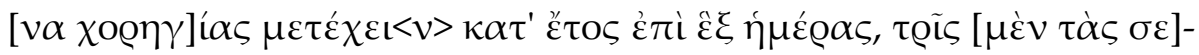

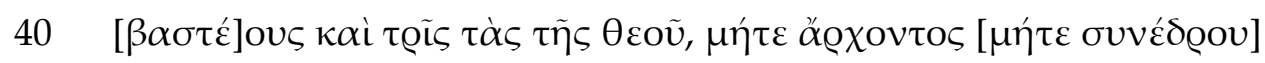

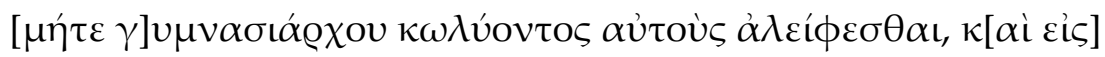

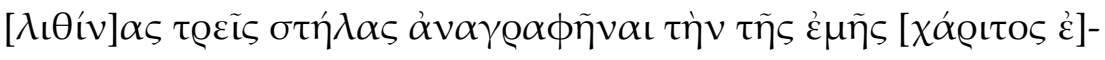

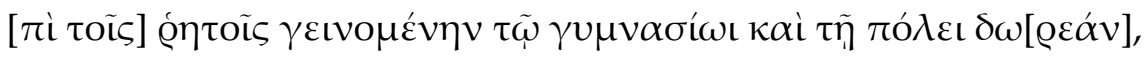

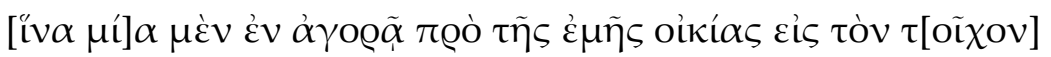

45 [

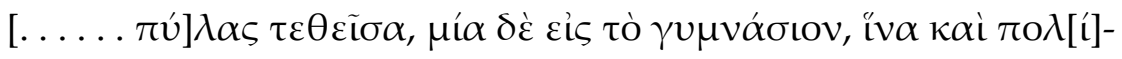

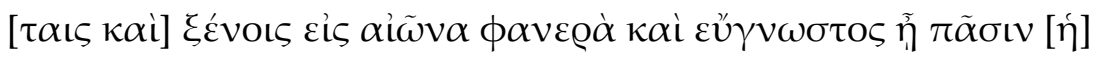

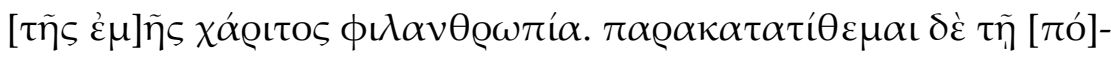

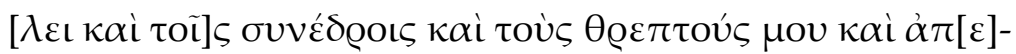

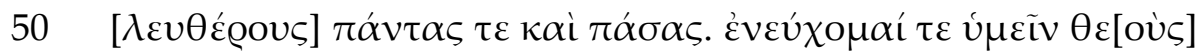

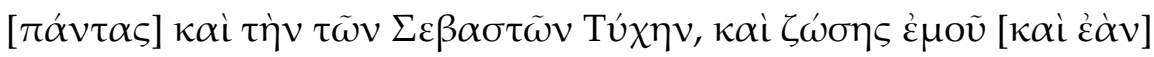

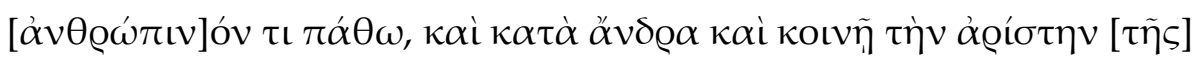

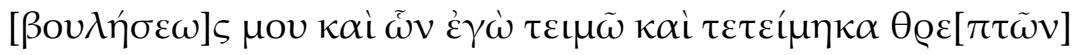

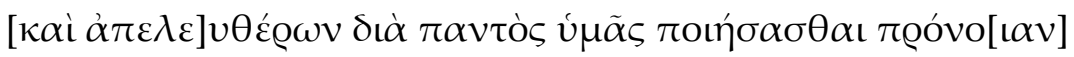

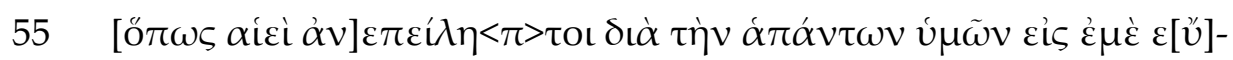

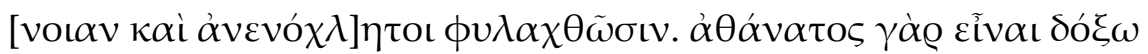

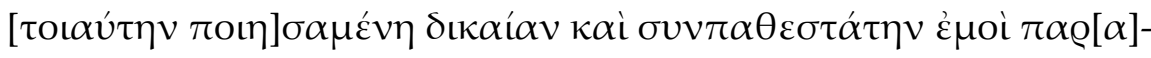

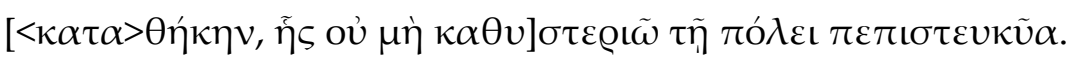

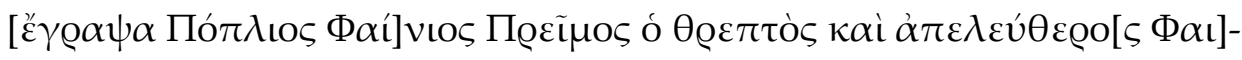




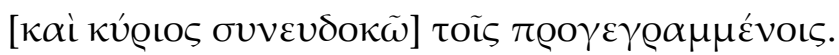

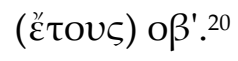

... to free the public treasury from this expenditure ... neither the gymnasion nor all the citizens nor all the foreigners who might live there, the ... (5) for the adornment and care of the body ... straight away the instruction, so that every year the archontes who are in charge at that time, whenever they franchise out the other public works, starting from the year of the strategos Aristopolis in accordance with the decrees of the synedroi of the polis and of the demos, (10) farm out the supplying of oil too. In doing so they should make every effort in order that immortal benefit is derived from my gift and the donation of the capital that is being lent and that those who receive the capital should give real security commensurate with the loan, so that oil may always be provided from the interest paid to the citizens of Gytheion and the (15) foreigners. The archontes and the synedroi must contribute all good faith and industry every year, in

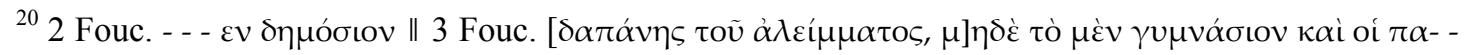

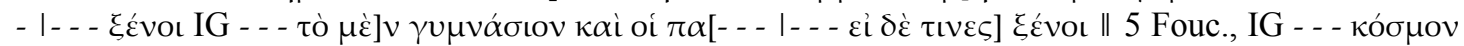

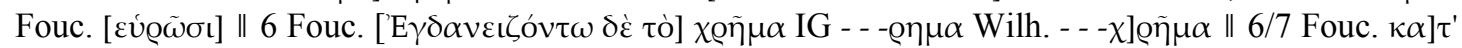

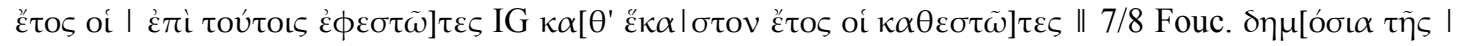

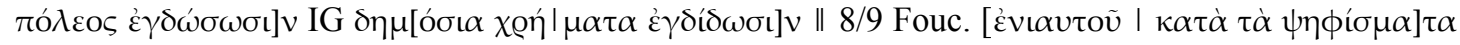

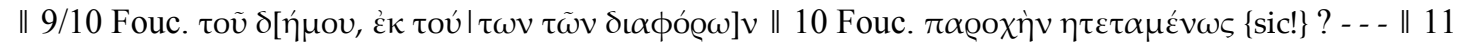

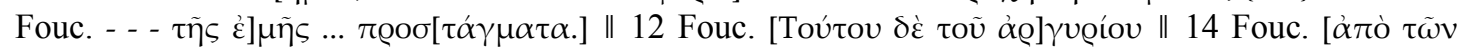

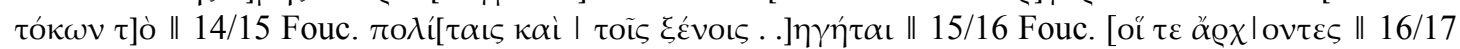

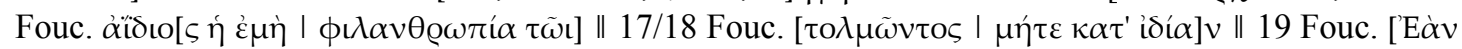

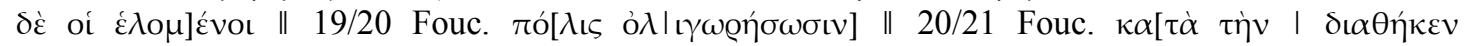

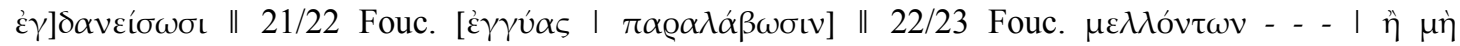

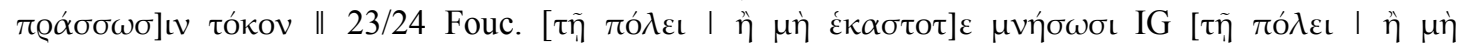

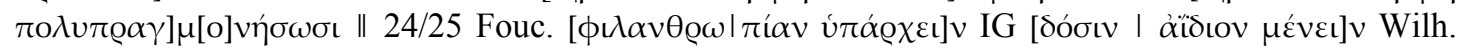

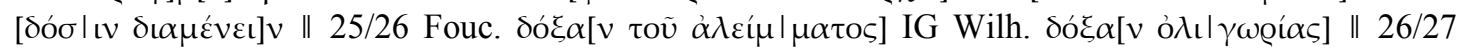

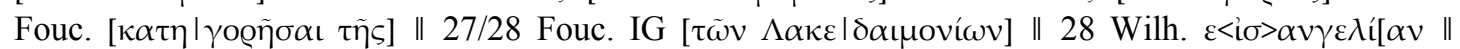

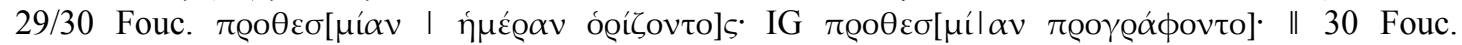

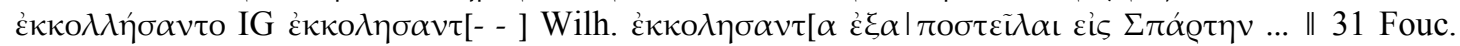

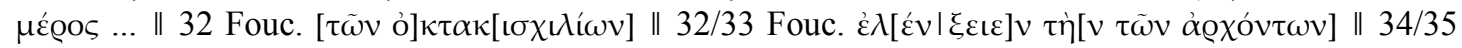

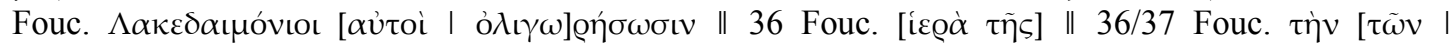

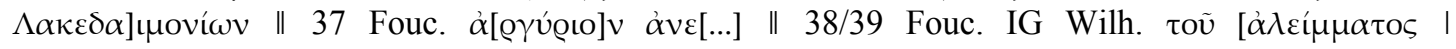

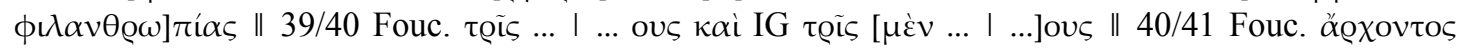

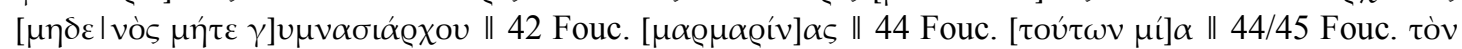

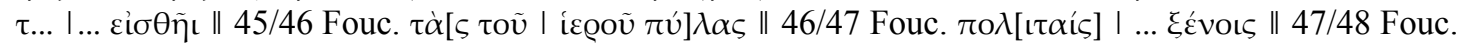

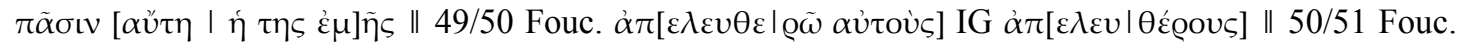

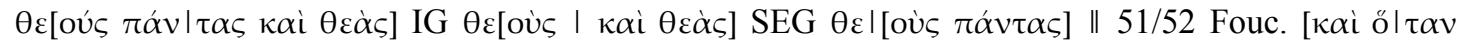

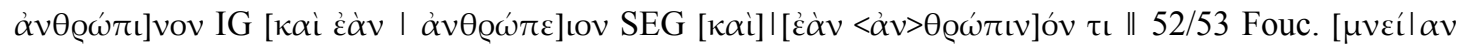

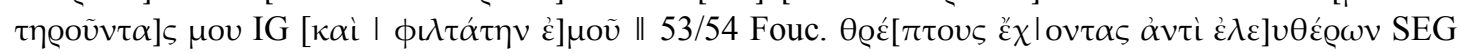

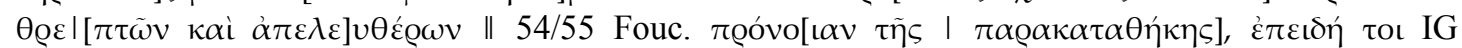

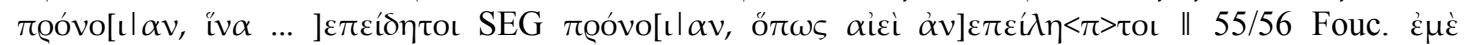

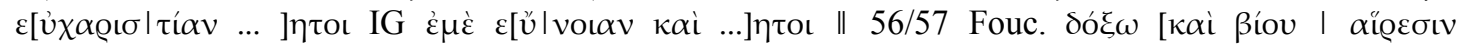

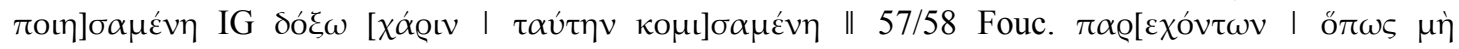

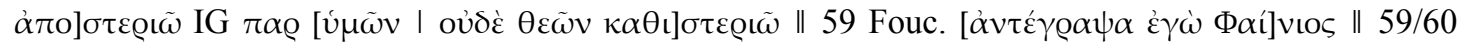

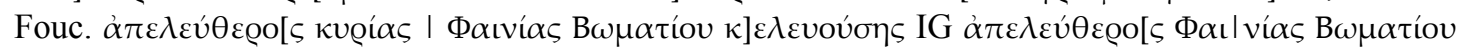

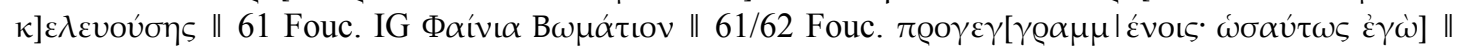

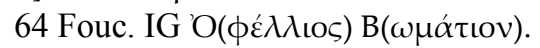


order that the supply of oil to the gymnasion and the polis remains everlasting, because no one should dare either in a private capacity nor publicly to neglect my donation. If the archontes who happen to be in charge in a given year or the synedroi or the polis (20) mismanage the eternal supply of oil or do not receive real security commensurate with the loan from those who are to pay the interest to the public treasury in order to provide for the polis all the unguent or do not take care to remain within the terms of my (25) donation of the capital and to avoid that the polis receives the reputation of negligence, it shall be possible for the one who wants of the Greeks or the Romans to prosecute the polis for neglect before the Assembly of the Gytheatai. The archontes shall receive the epangelia, and the prosecutor shall submit a written indictment and a time limit to the (30) synedroi. If they do not process it, they shall cut out from the public records ... a fourth of the eight thousand denarii shall belong to the prosecutor who has exposed the callousness of the Gytheatai, and the six thousand denarii shall belong to the polis of the Lakedaimonioi. If the Lakedaimonians (35) too neglect my donation, the six thousand denarii shall belong to the Dea Augusta, if a volunteer prosecutor has demonstrated the neglect of the Lakedaimonians and has transferred the capital to the Sebastoi. I also wish that the slaves shall share in the eternal supply of oil every year for six days, of which three (40) (should be) festival days of the Augusti and three festival days of the goddess, when no archon of synedros or gymnasiarchos shall prevent them from anointing themselves, and I wish that three stone stelai shall be inscribed with my donation and the terms on which it has been granted to the gymnasion and the polis, so that one will lean against the wall in the agora in front of my house (45), while one will be set up in the Kaisareion at the ... gates, and one at the gymnasion, so that the generosity of my donation shall be well-known and evident to everyone, both citizens and foreigners, forever.

I entrust to the polis and the synedroi my threptoi (50) as well as all my freedmen and freedwomen. I adjure you by all the gods and the Tyche of the Augusti that, both while I am alive and when I die, you pay most heed, both individually and collectively for all time to my wish and to those threptoi and freedmen whom I cherish and have always cherished (55) so that they will always be protected from seizure and harassment because of the benevolence of all of you towards me. For I shall appear to be immortal because I have made this just sacred trust (which is) very much in accordance with my feelings, in which matter I hope not to be failed because I have put my trust in the polis.

I, Publius Phaenios, threptos and freedman, (60) at the behest of Phaenia Aromation with the authorization of Publius Ophellius Crispus, phrontistēs and kyrios. I, Phaenia Aromation, approve all that is written above. I, Publius Ophellius Crispus, phrontistēs and kyrios, approve all that is written above.

Year 72

The capital given is - as we learn in 11. 32ssq. - 8000 denarii. For the administration of the capital Phaenia chose to "use" the polis-institutions rather than to form new bodies of experts. The city represented by its archontes is obliged to farm out the capital for a certain interest, whenever they farm out the other public works (11. 7-10). The interest is not specified in the part of the text that we have, but if we expect an interest about $10 \%,{ }^{21}$ Gytheion had 800 denarii every year to spend on oil. Phaenia defines the use of the interest, too: out of the money, oil has to be supplied not only for the citizens of Gytheion but also for the foreigners living there — which includes

${ }^{21}$ 10\%: IK Iasos II 248 (Iasos, Hadrianic); IG XII.7 515 (Amorgos, 2nd cent. BC); 16\%: IG IX.12.4 798 (Korfu, 2nd cent. BC); 6 2/3 \%: Bringmann 1995: Nr. 94 (Delphi, 160 BC). 
of course the group of Roman negotiarii she is belonging to (11. 14-15). Moreover she states that twice a year for three days each time, oil is to be handed out to slaves too (11. 38-41). The supply of oil for slaves - who had usually been forbidden to enter the gymnasion - is new but not without parallels. Tib. Claudius Diodotos in Argos praises himself for being the first and only to give out oil to free citizens as well as slaves. $^{22}$ The first period of oil supply for the slaves are three "augustean" days (11. 39-40), which I would like to interpret as the first three days of the Kaisareia of Gytheion, the festival established by the Hieros Nomos SEG 11.923. The Kaisareia last for six days of which the first three are dedicated to Augustus, Tiberius and Livia, who is worshipped as Tyche of the city, whereas the other three days are celebrated in honour of Germanicus, Drusus and T. Quinctius Flamininus. ${ }^{23}$ The second period "for the goddess" ( is worshipped throughout the Koinon of the Eleutherolacones, as well as for one of the Greek goddesses - Demeter (on the agora), Athena (on the acropolis) or Aphrodite Migonitis (on the island of Kranai). ${ }^{24}$ The fact that admitting slaves to the gymnasion is new to the citizens of Gytheion is stressed by the clause in 1. 40: neither the archontes nor the synedroi nor the gymnasiarchos are allowed to hinder the slaves. It seems quite sure that these magistrates had up to the donation been in charge of inhibiting slaves from entering the gymnasion. At first sight it seems surprising that one woman - the donor - can overrule existing laws of the polis in such an easy way, but we have to bear in mind that accepting the donation made a decision of the assemblies of Gytheion necessary. Therefore it was the city itself, which changed its prescriptions. This is one of the examples of the compromises made when establishing trust funds: in order to benefit from the money of the donation, the polis had to show its willingness to compromise too.

Generally the supply of oil is quite common in donations of wealthy citizens or peregrini: the polis Asopos, another perioecic city of Sparta and member of the Koinon of the Eleutherolacones, thanks the Spartan C. Iulius Eurykles for having ensured the supply of oil cis tòv $\alpha \hat{i} \tilde{\omega} v \alpha .{ }^{25}$ In Iasos, 5000 denarii are donated for the supply of the oil in the gymnasion of the young men. ${ }^{26}$ The closest parallel to our inscription can be found in Eretria (Euboia), where a certain Theopompos, son of Archedemos, donated 40000 drachmai out of eunoia (benevolence) in order to have oil bought. The text resembles the clauses we find in Gytheion, there is a similar system of ensuring the safety of the donation with archontes especially appointed for the trust fund. ${ }^{27}$ Other parallels come from Attaleia and Magnesia; some of the different prescriptions will be interpreted in the course of this article. ${ }^{28}$

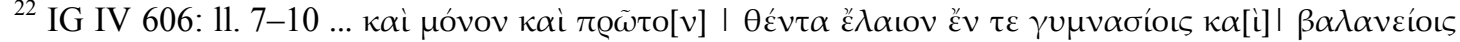

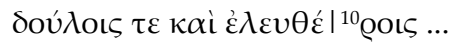

${ }^{23}$ SEG 11.923: Oliver 1989: 58-65; Harter-Uibopuu 2003: 217-221.

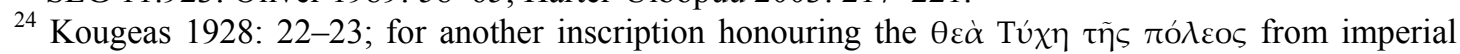
times see ibid. 44. Paus. 3.21.8-22.2 presents the sanctuaries and cults of Gytheion. IG V.1 1167 holds a honorific decree for Damonicidas, son of Rufus, who had been stratēgos of the Koinon of the Eleutherolacones as well as agōnothetēs of the Kaisareia in Gytheion (1. 7).

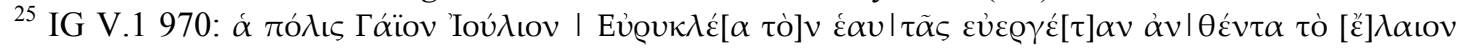
$\varepsilon<i>[\varsigma]^{\mid 5}$ tòv $\alpha i \tilde{\omega} v \alpha .$.

${ }^{26}$ IK Iasos II 248 (Iasos, Hadrianic; Laum 1914: Nr. 124).

${ }^{27}$ IG XII.9 236 (Eretria, 100 BC, Laum 1914: Nr. 61).

${ }^{28}$ Attaleia: TAM V.1-2.828 (Laum 1914: Nr. 72); Magnesia: IvMagn. 116 (Laum 1914: Nr. 125).
} 
The exact procedure of the farming out of the money received by the polis is not mentioned in the part of the inscription that we have (and it does not seem that it was in the lost beginning). There is only a quite general clause that - as referred to above - it was the duty of the archontes to sell the supplying of the oil as well as to give out the money on interest (11. 8-10). Those who receive the capital are obliged to give real security commensurate with the loan (11. 12-14). It seems that the reference to the system of public works in Gytheion (11. 7-8) was enough to state clearly the procedure she wanted to be followed. From other trust funds we know systems of egdaneismos more explicitly, one of the most interesting examples is the trust fund of Kritolaos, son of Alkimedon, from the island Amorgos (2nd cent. BC). ${ }^{29}$ The wealthy Aigaleian wanted to assure the heroization of his deceased son Aleximachos by installing an agōn and a banquet for the public. The capital of the trust fund was 2000 drachmai, donated to the polis. The egdaneismos of the money is to be carried out by the archōn, the prytaneis, the misthotai and Kritolaos himself in the month Apatourion for an interest of ten percent (11. 8-11). Apart from the donor we have city-officials here, who are attested in other inscriptions from Aigiale as well. Collecting of the interest was the duty of the boule — which was in charge of the hiera chrèmata too - with the archon and the logistai at their hand for the case of praxis, the exacting of due payments (11. 29-32): If one of the borrowers does not hand in the interest in the month Apatourion in the boulē, the boule, the logistai and the archōn shall exact payment at once, the same way as in case of the sacred money, up to the hemiolion. Kritolaos thus wanted his capital to be managed as the sacred treasures of the polis, which meant in fact as public money, and put it under control of the regular financial administration. The last officials we encounter in this context in Amorgos are the tamiai who were (again together with the boule and the archōn) in charge of handing over the income to the ones responsible for the administration of the object and purpose of the trust fund (11. 110-115).

Phaenia Aromation on the other hand focused more on the clauses ensuring that the polis and its officials really made every effort that was expected (1.15). Therefore a complex system of fines was established, which shows her main concerns. Lines 1718 state generally that nobody should dare privately or publicly to neglect the donation. From line 19 on, several special offences of city-officials are specified: neglecting or diminishing the supply of oil (11. 19-20), farming out the silver contrary to the prescriptions (11. 20-21), not receiving adequate real securities (11. 21-24), not remembering to remain within the terms of the trust fund (11.24-25). In order to ensure the maintenance of the standard she wanted, a system of voluntary prosecution is used, which was well known in Gytheion. Anybody who wanted to (o ßouló $\mu \varepsilon v o s$, 1. 26) - regardless whether he was Greek or Roman - was allowed and asked to indict the neglect, in fact to prosecute the case (11. 26-28). ${ }^{30}$ The procedure of asking the population of Gytheion to have an eye on the administration of their magistrates is well attested in Gytheion. The Hieros Nomos for the imperial cult of 15 AD shows the same system ${ }^{31}$ : 11. 17-18 and 11. 32-33 ask anybody who wants to indict mismanagement of the sacred money. In this case the boulomenos does not receive any reward if his accusations proved to be true, on the other hand it was stated explicitly that he did

\footnotetext{
${ }^{29}$ IG XII.7 515 (Laum 1914: Nr. 50).

${ }^{30}$ The law for the organisation of the isolympic games in Neapolis has a similar clause stating that the boulomenos could be either a foreigner or a Neapolites (SEG 37.356 [1], 1. 26).

${ }^{31}$ SEG 11.923, cf. above note 24.
} 
not risk any of his own fortune if he lost his case (11. 17-18). ${ }^{32}$ In our inscription on the trust fund there is no explicit clause exempting the boulomenos from risking his own fortune, on the other hand there was a reward for the successful litigant, as we shall see later on (11. 31-34).

The archontes had to receive the epangelia (11. 27-28). There might be an Athenian pattern used in Gytheion in this procedure: in Athenian law we find the epangelia as a preliminary denunciation necessary before raising a dokimasia against a public speaker, ${ }^{33}$ but it could as well be that the word simply means "formal denunciation". ${ }^{34}$ A. Wilhelm wanted to change the Greek text here and read eisangelia ${ }^{35}$ but I do not see any need for this obvious "Athenisation" of the local procedure. Following the epangelia in front of the archontes we find again the boulomenos acting: he hands over a writ (antigraphon) and the time-limit (prothesmia) to the council, the synedroi

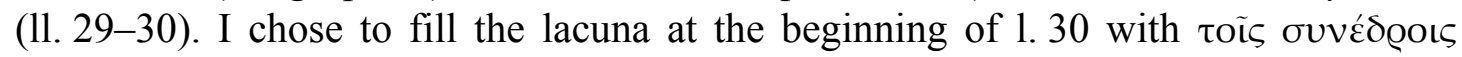
because after having heard that the archontes had accepted the epangelia and the kategoros had a copy of the writ (1.29), one should expect to find the bench of jurors to whom the writ is handed over. The fact that the synedroi and the archontes are mentioned as possible defendants does not necessarily contradict this procedure. The council was big enough to be expected to judge the administration of its members fairly.

The inscription shows very well that the role of the boulomenos in the proceedings is not finished after having indicted the abuse; he is called kategoros and will thus have acted as the prosecutor in the trial (1.29). Striking is the fact that the prosecutor seems to have set a time-limit. ${ }^{36}$ One would expect this to be done by the council, who appears to have acted as the bench of jurors (1.30). I think that this is not standard procedural law in Gytheion but would suggest that Phaenia herself (or her advisors) insisted on this treatment of the action. It seems that she did not trust the city-officials enough in a moment when the polis itself — represented by these officials - was under suspicion, therefore she entrusted the boulomenos with the capacity not only to start the procedure but also to ensure its progress. If the kategoros succeeded in proving the rhathymia, the callousness, of the Gytheatai, he himself was to receive 2000 denarii, the other 6000 denarii were to go to the city of Sparta (11. 31-34).

It is this part of the text concerning the procedural details, where I have made most of the changes in the supplementation of the lacunae. ${ }^{37}$ The version of Wilhelm and his

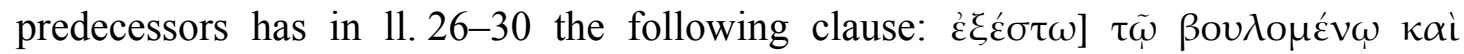

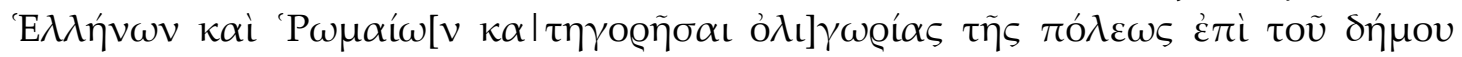

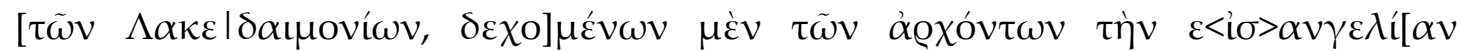

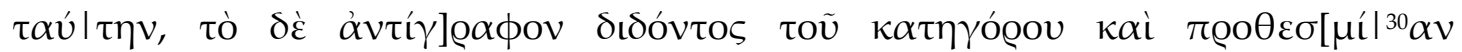

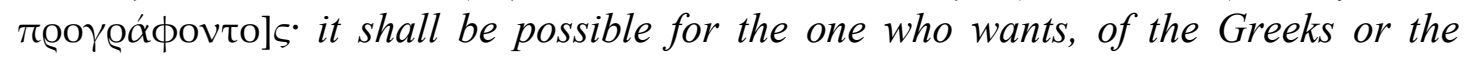

\footnotetext{
${ }^{32}$ L. Wenger (1929: 323-324), who supposes that IG V.1 1145, 1. 54 might be a hint on the same procedure; Ziebarth 1897: 623-624.

${ }^{33}$ Harrison 1998: 204; Aischin. 1.2.32.63.81.

${ }^{34}$ Cf. SEG 37.356 [1], 1. 24; SB 4434 (2nd cent. AD).

${ }^{35}$ Wilhelm 1951: 99-100.

${ }^{36}$ In cases of public interest a prescribed period is found quite often, but it is never set by the katēgoros. Cf. Thür - Taeuber 1994: 42 (IPArk 3 = IG V.2 6A); 69 (IPArk $5=$ Syll. $^{3}$ 306).

${ }^{37} \mathrm{Cf}$. above at note 35 .
} 
Romans, to prosecute the polis for neglect before the demos of the Lakedaimonioi. The archontes shall receive the eisangelia, and the prosecutor shall submit a written indictment and the prescribed time limit (30). This means that the trial would have been held in Sparta in front of Spartan dikastai. Two aspects of this version were bothering me: first of all the procedure of calling officials to account, the euthyna which is for sure the background of our procedure here - would have been held in a foreign city. This practice is without parallel in the ancient sources. ${ }^{38}$ Of course I am not claiming that foreign cities or judges were never called to act in internal affairs of Greek poleis. In fact that happened quite often as the sources in international arbitration show us, but the system worked differently. Either two poleis agreed on a third party to adjudicate a quarrel they had (which was the usual case of interstate arbitration), or a city having internal trouble might call on another city to send judges or even choose a special group of individuals. ${ }^{39}$ A system like the one proposed by the supplement of transferring an internal affair obligatorily to the jurisdiction of another polis is very unlikely. My second reason for doubting these supplements is that Sparta could have expected great benefit from the misbehaviour of the Gytheatai. If it ruled the little polis guilty of misconduct according to the statute of the trust fund, it was to receive 6000 denarii. I do not think that an impartial judgment could have been expected when the judges were supposed to receive three fourths of the sum at issue. ${ }^{40}$ I do not see any reason to "invent" a trial in front of Spartan judges and would rather stay within the polis of Gytheion regarding the matter as a special procedure of

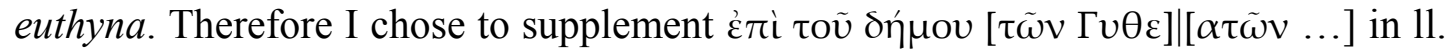
$27-28$.

One more interesting point remains to discuss regarding the procedure: in 1.30 we

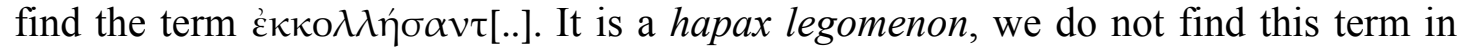
ancient literature, nor in epigraphical or papyrological sources. If the synedroi refused to receive (i.e. to carry out the trial), somebody was asked to do the $\dot{\kappa} \kappa \kappa o \lambda \tilde{\alpha} v$, but the text leaves no clue to what it was supposed to be or what was to follow. A. Wilhelm tried to explain the word as "cutting files out of the roll" quite convincingly, thinking of a roll consisting of several sheets glued together. ${ }^{41}$ Still I cannot follow his supplements and interpretation of the clause. As I explained above, Wilhelm thinks that the trial should be held in front of the démos of the Lacedaemonians. Nevertheless he seems to interpret the archontes in 1.28 as magistrates of Gytheion when stating that if the archontes of the Gytheatai did not accept the indictment against them, the boulomenos had to unglue the files out of the records and send them to Sparta. Several points in this explanation seem misleading. Why should the written indictment already be bound together with other public files when the case had not yet been accepted by the city's officials? Are we to expect the writ in the public archives

\footnotetext{
${ }^{38}$ Cf. now Fröhlich 2004.

${ }^{39}$ Marshall 1980: 626-661; Raeder 1912; Robert 1973: 765-782.

${ }^{40}$ Two cases in which the judges required the land at issue for themselves are known, and already in antiquity this behaviour was regarded as a shame. Liv. 3.71-72; cf. 4.1.4, 4.7.4-6, 4.11.2-7; Dion. Hal. 11.52 (Aricia and Ardea have a dispute over a certain piece of land and Rome is asked to act as an arbitrator, but takes the land in question for itself. For the discussion in the senate over this treatment of the litigants see Liv. 3.72). Cic. de off. 1.10.33; Val. Max. 7.3.4 (Q. Fabius Labeo is asked to decide between Nola and Neapolis). See Harter-Uibopuu 1998: 165-166.

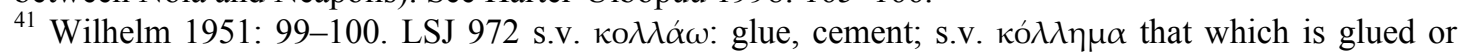
fastened together, especially of the sheets of papyrus fastened together to form a roll (PMag Par. 1.2068, 2513; BGU 16.9).
} 
without the trial being held yet? Why should the writ be sent to Sparta when -

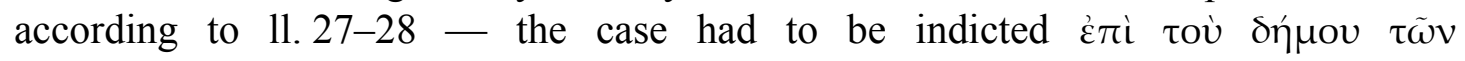
$\Lambda \alpha \kappa \varepsilon \delta \alpha$ uoví $\omega v$ anyway? Why is the polis of Sparta always called - correctly $\Lambda \alpha \kappa \varepsilon \delta \alpha$ uóviol (11.34 and 36-37) with the exception of Wilhelm's suggested emendation in 1.31, where he uses topographical expression $\Sigma \pi \alpha \dot{\alpha} \varrho \tau \eta ?^{42}$ I would rather recommend a different interpretation of the proceedings: the kategoros was to hand over the writ to the synedroi. If they did not process it, somebody is called to cut out the files of the trust fund itself from the books of records, therefore I would

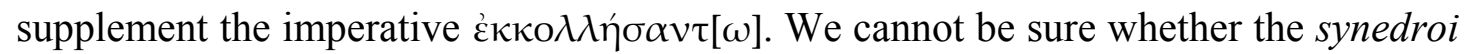
themselves were asked to do so - which is rather unlikely since they just proved their unwillingness to cooperate - or any other official or private person. The meaning of the "cutting out" must be understood in the light of the following lines 31-34: if the callousness of the Gytheatai could be shown, one fourth of the trust fund's capital was to go to the kateggoros, the other three fourths to the Lacedaemonians. The city was thus losing the capital donated by Phaenia: the acts were taken out of the city's records just as they had been accepted and registered in the beginning. The grammatophylakeion, the public archive, is attested for Gytheion, ${ }^{43}$ it will have contained the terms and prescriptions of Phaenia's donation too. The trial itself was to be held in Gytheion, only if through this trial — or by preventing it - the fault of the Gytheatai was proven, was the money to be sent to the Lacedaemonians. Still Phaenia thinks even one step farther: what was to happen if Sparta too was unworthy and neglected her benevolence? Again a boulomenos could undertake it to indict this fact, show the neglect and hand over the money to the priests of the cult of the sebaste thea, the Diva Augusta, Livia. ${ }^{44}$

One topic we find throughout the whole text is Phaenia's wish to be respected for her benevolence and to be remembered. ${ }^{45}$ Clearly enough it is herself and not the polis who formulates the publication clause and states that three copies of the text should be inscribed on stone stelai and put up in prominent places in order to remember the donation. It is disregard and neglect that she despises enough to punish two cities with the withdrawal of the money she gave. Therefore in 11. 17-18 private and public neglect of her donation become actionable. She might even have wanted to be mentioned every time the money was needed like M. Vettius Philon in Styberra in Macedonia. Inscriptions tell us that he is named at the beginning of every ephebic list of the polis as donor of the oil of that year. ${ }^{46}$ The aim of Phaenia thus was not only selfless benevolence for the city, but she had precisely calculated thoughts on the effect of her donation: she and her family of traders were to be renowned, mentioned and remembered. Together with the social reputation they could expect economic benefit. This way the establishment of a trust fund can be seen as an ancient - and modern - form of advertisement too.

\footnotetext{
${ }^{42}$ Wilhelm 1951: 100.

${ }^{43}$ SEG 11.923, 1. 37; cf. IG V.1 20 A 1. 4 for Sparta and IG V.1 1114, 1. 16 for Geronthrai.

${ }^{44} \mathrm{Cf}$. above note 5: Livia had just been consecrated in the year $42 \mathrm{AD}$ by Claudius and was hence worshipped as diva augusta; for Sparta: Cartledge - Spawforth 1989: 102-103.

${ }^{45}$ L1. 11-12; 1. 18; 11. 24-25; 11. 34-35; 11. 52-53; 11. 55-56.

${ }^{46}$ Papazoglou 1988: 233-259, esp. 245.
} 


\section{The Parakatatheke}

L1. 48-58 show another important concern of the donor Phaenia Aromation: she wanted to take care of her threptoi and apeleutheroi. ${ }^{47}$ Therefore she entrusted them to the polis, using the same term that is used in financial transactions, $\tau \alpha \varrho \alpha \kappa \alpha \tau \alpha \tau i \theta \eta \mu$. The procedure is known from other epigraphical evidence as well, usually slaves who were freed were entrusted to a sanctuary, which guaranteed that they were not reenslaved. An inscription from Stiris in Phocis shows such a parakatathèke to the polis and the Koinon of the Phocians (IG IX.1 34):

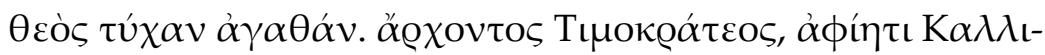

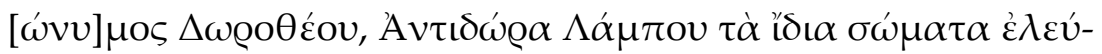

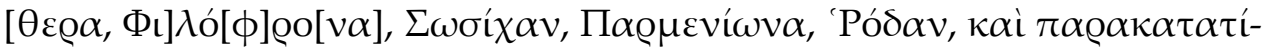

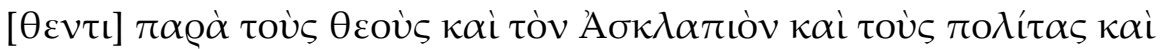

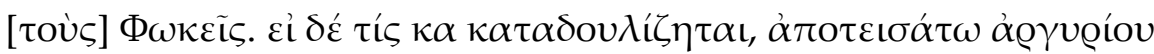

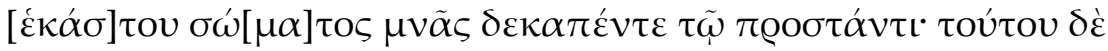

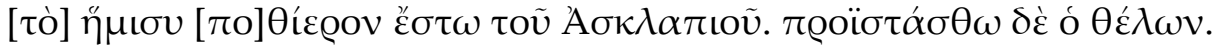

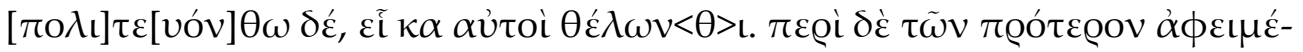

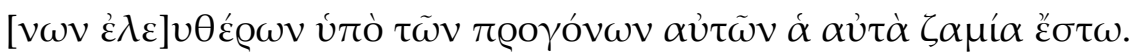

God. Good Fortune. In the year of the archōn Timokrates. Kallionymos, son of Dorotheos, and Antidora, daughter of Lampos, release their own slaves Philophron, Sosicha, Parmenion, Rhoda, into freedom, entrusting them to the gods and Asklepios and the citizens and the Phocians. If somebody enslaves them again, he shall pay for every slave 15 minai to the prostas, half of which shall be consecrated to Asklepios; whoever wants to can be the prostas. They shall be citizens if they want to. Regarding freedmen released earlier by their ancestors, the same fine shall apply.

While the text from Gytheion is quite general and asks the polis and its citizens to protect the freedmen of Phaenia because of their benevolence towards the rich donor, the text from Stiris shows a more specific legal procedure: anyone who wants to -

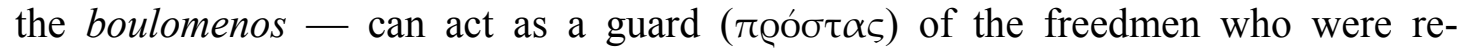
enslaved. He will be entitled to receive 15 minai for every slave but has to dedicate half of the sum to the sanctuary of Asklepios. ${ }^{48}$ On the other hand the text from Stiris is a proper manumission record, which the text from Gytheion is not. The implication of both texts is still the same: the former slaves are to be protected from seizure and harassment. This procedure seems very clear in the case of the $\alpha \pi \varepsilon \lambda \varepsilon v \dot{\theta \varepsilon} \varepsilon \mathrm{ol}$ of the inscription, the manumitted slaves, but Phaenia has as a second group of persons: the

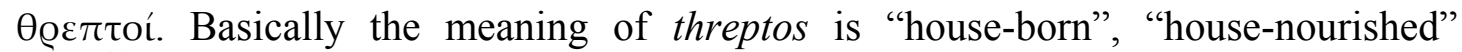
slave $^{49}$, but two facts are likely to rule out the meaning "slave" in our inscription. In the first place, slaves would not be entrusted to the city in order to provide them from reenslavement or other harassments. Moreover Publius Phaenius Primus calls himself

\footnotetext{
${ }^{47}$ Wilhelm (1951: 93) presents his corrections to the text without the separation of lines, which has obviously been supplied by the editor of the SEG. In my text I try to stay closer to the length of the lines as presented in IG but with the emendations of Wilhelm.

${ }^{48}$ Albrecht 1978: 118, 213-215.

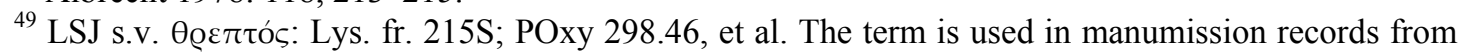
Central Greece meaning "slave" as well as in Delphi: IG VII 3326, 1. 5; 3368, 1. 1; 3376, 1. 5 (where the

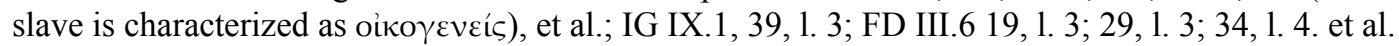


apeleutheros and threptos proudly (1. 59). Thus the second interpretation in the LSJ as "adopted foundling" seems to point into the right direction. ${ }^{50}$ I guess that in our case, a very special status is described: the slave was cherished and honoured, and even if not formerly adopted after his manumission taken into the family. Surely enough he was proud of the special links to his master's family. IG V.1 1170 shows another threptos from Gytheion. Lykos, son of Zenon, paid for the erection of a statue of Popilius Melas, which was granted by the polis. Again it seems that the (former) slave seems to be proud enough to take the costs and mention his status.

At last one more point needs clarification: what kind of legal act is the parakatathe $\bar{e} \bar{e}$ that is described in our inscription? Parakatathēke as a legal term means the deposit of money or property entrusted to one's care. ${ }^{51}$ Moreover it is used for the entrustment of persons to guardians, as is described by Demosthenes 28.15 .

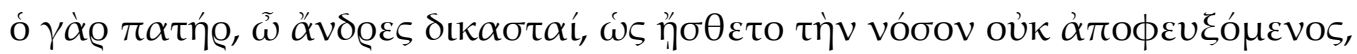

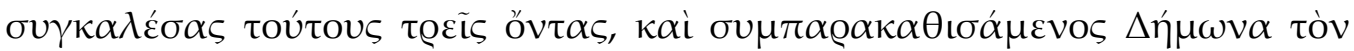

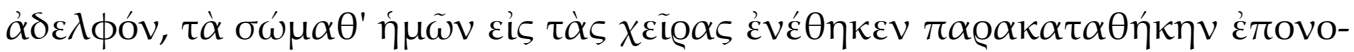
$\mu \alpha \dot{\zeta} \zeta \omega v, \ldots$

For my father, men of the jury, when he saw that he was not to recover from his sickness, called together these three men, and causing his brother Demon to sit with them by his side, placed our persons in their hands, calling us a sacred deposit.

In the inscription from Gytheion, P. Foucart would like to see a manumission combined with the entrustment of the manumitted to the state, just as we have seen it in the inscription from Stiris. ${ }^{52} \mathrm{~B}$. Laum agrees with this interpretation and states that the polis is asked to treat the slaves as freedmen in every way and to take care that they are regarded as such. ${ }^{53} \mathrm{~A}$. Wilhelm contests this view and maintains the contrary: the apeleutheroi and the threptoi were two different groups of people and there was no mention of a manumission. Nevertheless, he says, it was Phaenia's aim to entrust both groups to the guardianship of the state, which she expects to be granted gladly out of gratitude for her generous gift. ${ }^{54}$ Still Wilhelm offers no explanation of the kind of protection that is expected for slaves who are owned by a private person. Therefore I think that in this inscription Phaenia expresses her intent — legally not binding — to free her favourite slaves, her threptoi, probably when she dies. Neither this expression of her will nor the parakatathēke are legal acts, therefore none of the slaves can rely on more than the honesty of their mistress, and the polis cannot be forced to intervene in any case of harassment of one of the freedmen. On the other hand, the social status and reputation of Phaenia would bind both her and the polis to remain within the terms of their promises. Demosthenes' father relied on the same force when he "deposited" his children into the hands of his friends.

$$
* * *
$$

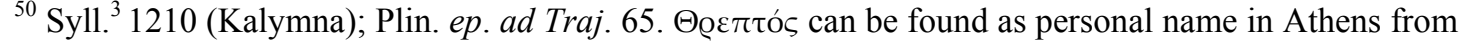
the 1st cent. AD on: IG II ${ }^{2} 1973$ III 1. 68; 2018 IV 1. 145; 2044 II 1. 113; 2046 II 1. 48; 2103 A II 1. 87.

${ }^{51}$ Cf. IG II ${ }^{2}$ 1407, 1. 42; IG V.2 159 with Thür - Taeuber 1994: 1-11 (Nr.1).

${ }^{52}$ LeBas - Waddington 1837: 127.

${ }_{53}^{53}$ Laum 1914: 14.

${ }^{54}$ Wilhelm 1951: 93-97.
} 
Phaenia Aromation, a rich Roman woman, had bestowed a generous gift on her hometown Gytheion, which was on the other hand bound to certain regulations. In this inscription she presents herself not only as a noble citizen, but as a caring mistress of her slaves too. The combination of the regulations for the trust fund and the announcement of her will for her slaves leads me to assume that this stone had not been put up as one of the three official copies of 11. 41-48 but might have been made on her own initiative. After having approved of accepting Phaenia's donation, the city will have put up three copies of the decree, probably including the text of Phaenia's proposal, but not her regulation for her slaves. The fact that our text might not be one of these copies would explain the very personal hypographe at the end of the text, it might be seen as a letter to the public instead. As we have seen, her reputation and status seem to have been Phaenia's major concern: in 11. 56-58 she hopes that she might be regarded as immortal through her acts of benevolence. By putting up the

stone that has survived until today, her wish is granted, if only in scientific discussions.

Dr. Kaja Harter-Uibopuu

Kommission für Antike Rechtsgeschichte

Österreichische Akademie der Wissenschaften, Wien

E-mail:kaja.harter@oeaw.ac.at 


\section{References}

Albrecht, K. D. (1978) Rechtsprobleme in den Freilassungen der Böoter, Phoker, Dorier, Ost- und Westlokrer. Paderborn: Schöningh.

Bowersock, G. W. (1966) Augustus and the Greek World. Oxford: Clarendon Press.

Bringmann, K. (1995) Schenkungen hellenistischer Herrscher an griechische Städte und Heiligtümer I. Berlin: Akademie Verlag.

Bursian, C. (1872) Geographie von Griechenland II. Leipzig: Teubner.

Cartledge, P. - Spawforth, A. ( $\left.{ }^{2} 2002\right)$ Hellenistic and Roman Sparta. A Tale of Two Cities. London, New York: Routledge.

Chrimes, K. T. (1952) Ancient Sparta. Manchester: Manchester University Press.

d'Arms, J. H. (1981) Commerce and Social Standing in Ancient Rome. Cambridge: Harvard University Press.

Fröhlich, P. (2004) Les cités Grecques et le contrôle des magistrats. École pratique des hautes études III 33, Geneva: Droz.

Grether, G. (1946) 'Livia and the Roman Imperial Cult.' - AJPh 67, 222-252.

Harrison, A. R. W. ( $\left.{ }^{2} 1998\right)$ The Law of Athens II. London: Bristol Classical Press.

Harter-Uibopuu, K. (1998) 'Das zwischenstaatliche Schiedsverfahren im Achäischen Koinon. Zur friedlichen Streitbeilegung nach den epigraphischen Quellen.' Akten der Gesellschaft für griechische und hellenistische Rechtsgeschichte, Bd. 12. Köln, Weimar, Wien: Böhlau, 165-166.

Harter-Uibopuu, K. (2003) 'Kaiserkult und Kaiserverehrung in den Koina des griechischen Mutterlandes.' - H. Cancik, K. Hitzl (Hrsg.), Die Praxis der Herrscherverehrung in Rom und seinen Provinzen, Tübingen: Mohr Siebeck, 209-231.

Kahrstedt, U. (1954) Das wirtschaftliche Gesicht Griechenlands in der Kaiserzeit. Bern: A. Francke.

Kaser, M. (1955) Das Römische Privatrecht I. München: Beck.

Kougeas, S. B. (1928) 'Е

Laum, B. (1914) Stiftungen in der griechischen und römischen Antike II. Berlin: Teubner.

Le Roy, C. (1978) 'Richesse et exploitation en Laconie au $1^{\text {er }}$ siècle av. J.-C.' Ktema 3, 261-266.

LeBas, P. - Waddington, W. H. (1837) Inscriptions Grecques et Latines recueillies en Grèce et en Asie mineure II. Paris: Firmin Didot.

Marshall, A. J. (1980) 'The Survival and Development of International Jurisdiction in the Greek World under Roman Rule.' - $A N R W$ II 13, 626-661.

Mitteis, L. (1891) Reichsrecht und Volksrecht in den östlichen Provinzen des römischen Kaiserreiches. Leipzig: Teubner (Olms 1963).

Oliver, J. H. (1989) Greek Constitutions of Early Roman Emperors from Inscriptions and Papyri. Philadelphia: American Philosophical Society.

Papazoglou, F. (1988) 'Les stèles éphébiques de Stuberra.' - Chiron 18, 233-270.

Raeder, A. (1912) L'arbitrage international chez les Hellènes. Kristiania: Aschehoug.

Robert, L. (1973) 'Les juges étrangers dans la cité grecque.' - EENION, FS Zepos I, hrsg. von Ernst von Caemmerer, Athen, Freiburg, Köln: Katsikalis, 765-782.

Rupprecht, H. A. (1986) 'Zur Frage der Frauentutel im römischen Ägypten.' G. Wesener et al. (Hrsg.), Beiträge zur antiken Rechtsgeschichte, Festschrift für Arnold Kränzlein, Graz: Leykam, 95-102.

Taeuber, H. (1994) 'Stifterinnen im griechischen Osten.' - E. Specht (Hrsg.), Frauenreichtum: Die Frau als Wirtschaftsfaktor im Altertum, Wien: Wiener Frauenverlag, 199-219. 
Thür, G. - Taeuber, H. (1994) Prozeßrechtliche Inschriften der griechischen Poleis: Arkadien (IPArk). Wien: Akademieverlag. (Veröffentlichungen der Kommission für Antike Rechtsgeschichte 8; SB Österr. Akad. d. Wiss. 607.)

Wenger, L. (1929) 'Griechische Urkunden zum Kaiserkult und zum Grabrecht.' ZRG 49, 322-324.

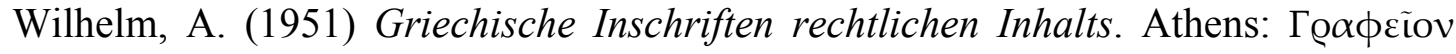

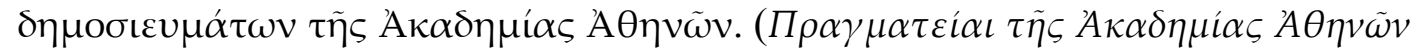
17.1.)

Ziebarth, E. (1897) 'Popularklagen mit Delatorenprämien nach griechischem Recht.' - Hermes 32, 623-624. 